\title{
MEKANISME PELAKSANAAN KLIRING PADA KANTOR PERWAKILAN (KPW) BANK INDONESIA PROVINSI SUMATERA BARAT
}

\author{
Hilda Elvira, Elva Dona \\ Akademi Keuangan dan Perbankan Padang
}

\begin{abstract}
ABSTRAK
Seiring dengan perkembangan globalisasi, kebutuhan dalam bertransaksi juga semakin meningkat. Sebagai penyelenggara kliring, Bank Indonesia Provinsi Sumatera Barat berperan penting dalam kelancaran transaksi pembayaran. Tujuan dari penelitian ini adalah untuk mengetahui bagaimana mekanisme pelaksanaan kliring pada Kantor Perwakilan Bank Indonesia Provinsi Sumatera Barat, apakah telah sesuai dengan prosedur yang telah ditetapkan. Metode penelitian yang digunakan dalam Tugas Akhir ini adalah metode deskriptif kualitatif, dengan menggunakan informasi dan data yang ada pada perpustakaan Bank Indonesia Provinsi Sumatera Barat. Dalam mekanisme pelaksanaan kliring, Kantor Perwakilan Bank Indonesia Provinsi Sumatera Barat selaku Penyelenggara Kliring Lokal (PKL) melaksanakan prosedur kliring debet, sementara kliring kredit dilakukan oleh Penyelenggara Kliring Nasional (Bank Indonesia Pusat).
\end{abstract}

Kata Kunci: Mekanisme Pelaksanaan Kliring

\section{Latar Belakang}

Dalam kehidupan sehari-hari masyarakat memiliki kebutuhan yang berbeda-beda, kebutuhan yang dimaksud adalah kebutuhan dalam bertransaksi yang semakin meningkat seiring dengan globalisasi perekonomian dunia. Para penjual yang menginginkan usahanya terus berkembang dengan cara pembayaran yang dilakukan bermacam-macam. Karena cara pembayaran yang bermacam-macam membuat bank memiliki inisiatif untuk mempermudah cara pembayaran dalam transaksi oleh penjual dan pembeli.

Salah satu fungsi utama dari bank adalah melakukan pertukaran uang dalam bertransaksi. Mekanisme pembayaran yang lebih dari satu pihak ke pihak yang lainnya jika kedua belah pihak memiliki rekening yang sama akan mempermudah proses transaksi, dan jika pembayaran dilakukan dengan rekening yang berbeda atau tidak berada disatu daerah maka proses transaksi akan terkendala.

Cara penyelesaian utang piutang yang menyangkut pada bank akan memerlukan biaya yang besar, tenaga yang kurang efektif dan juga memerlukan waktu yang cukup lama. Dengan demikian kegiatan operasional perbankan akan terhambat. Oleh karena itu, muncul suatu gagasan untuk 
membentuk lembaga kliring yang kemudian diselenggarakan oleh Bank Indonesia sebagai bank sentral yang dimulai pada tanggal 7 Maret 1967.

Dengan adanya lembaga kliring, berbagai masalah seperti waktu pertemuan, tempat, siapa yang hadir, besarnya dana yang dibutuhkan untuk penyelesaian utang piutang dan sebagainya, telah ditentukan dan diorganisir. Tujuan yang diinginkan dari terbentuknya lembaga kliring adalah untuk mempermudah pembayaran dalam rangka memperlancar transaksi perekonomian dengan perantara perbankan sebagai peserta kliring dan Bank Indonesia sebagai penyelenggara kliring. Selain itu, pemakaian alat-alat lalu lintas pembayaran giral seperti, cek, nota debet, nota kredit, dan lainnya diharapkan akan lebih meningkat.

Kliring merupakan pertukaran warkat atau data keuangan antara bank baik atas nama bank maupun atas nama nasabah yang hasil perhitungannya diselesaikan dalam waktu tertentu. Penyelenggaraan kliring pada awalnya dilakukan secara manual, sejalan dengan meningkatnya transaksi perekomian nasional hal ini meyebabkan penyelenggaraan kliring secara manual tidak efektif dan tidak efisien.

Melihat kondisi tersebut Direksi Bank Indonesia dengan SKBI No. 21/9/KEP/DIR tanggal 23 Mei 1998, kemudian menetapkan untuk mengubah sistem pembayaran lokal dari sistem manual menjadi sistem otomasi kliring. Walaupun demikian sistem otomasi kliring lokal untuk memproses kliring penyerahan baru diimplementasikan pada tanggal 14 Juni 1990. Sementara untuk proses kliring pengembalian tetap dilakukan secara manual, pada tahun 1994 diganti dengan sistem semi otomasi yang kemudian dikenal dengan Sistem Otomasi Kliring Lokal (SOKL).

Kliring dilaksanakan di Bank Indonesia (BI) dengan menggunakan Sistem Kliring Nasional Bank Indonesia (SKNBI). Sistem ini baru ditetapkan, dimana sebelumnya menggunakan Sistem Otomasi Kliring Lokal (SOKL). Pada daerah didalam wilayah Indonesia yang tidak ada Bank Indonesia maka proses kliring dilakukan oleh salah satu bank yang ditunjuk oleh Bank Indonesia pada daerah tersebut sehingga selain berfungsi sebagai Bank Umum yang melayani nasabah, maka bank yang telah ditunjuk tersebut berfungsi sebagai bank pelaksana Kliring Lokal.

\section{Rumusan Masalah}

Setelah mempelajari latar belakang masalah diatas, maka rumusan masalah yang dapat diambil sebagai kajian dalam Tugas Akhir ini adalah bagaimana mekanisme pelaksanaan kliring pada Kantor Perwakilan (KPw) Bank Indonesia Provinsi Sumatera Barat.

\section{Tinjauan Pustaka Pengertian Kliring}

Kliring berasal dari istilah kata dalam bahasa inggris "Clearing" sebagai suatu istilah dalam dunia perbankan dan keuangan yang menunjukkan suatu aktivitas yang berjalan sejak saat terjadinya kesepakatan untuk suatu transaksi hingga selesainya pelaksanaan kesepakatan tersebut. Kliring sangat dibutuhkan sebab kecepatan dalam dunia perdagangan jauh 
lebih cepat dari pada waktu yang dibutuhkan guna melengkapi pelaksanaan aset transaksi.

Kliring melibatkan manajemen dari paska perdagangan, pra penyelesaian eksposur kredit, guna memastikan bahwa transaksi dagang terselesaikan sesuai dengan aturan pasar, walaupun pembeli maupun penjual menjadi tidak mampu melaksanakan penyelesaian kesepakatannya.

Kasmir, dalam bukunya Dasar-Dasar Perbankan, mendefinisikan kliring sebagai jasa penyelesaian hutang-piutang antar bank dengan cara saling menyerahkan warkat-warkat yang akan dikliringkan di lembaga kliring.

Pengertian kliring menurut Peraturan Bank Indonesia No.7/18/PBI/2005 tanggal 22 Juli 2005 adalah:

"Kliring merupakan pertukaran warkat atau data keuangan elektronik antar bank baik atas nama bank maupun nasabah yang hasil perhitungannya diselesaikan pada waktu tertentu".

Berdasarkan berbagai pendapat yang telah dikemukakan mengenai pengertian kliring diatas, maka dapat disimpulkan bahwa kliring merupakan suatu tata cara perhiungan utang piutang dalam bentuk surat-surat dagang dan surat-surat berharga dari suatu bank terhadap bank lainnya, dengan maksud agar penyelesaiannya dapat terselenggara dengan mudah dan tata cara yang aman, serta untuk memperluas dan memperlancar lalu lintas pembayaran giral.

\section{Jenis-Jenis Sistem Kliring}

a. Sistem Kliring Manual

Sistem manual adalah sistem penyelenggaraan kliring lokal yang dalam pelaksanaan perhitungan, pembuatan Bilyet Saldo Kliring serta pemilahan warkat dilakukan secara manual oleh setiap peserta kliring. Dalam sistem manual kliring dilakukan oleh non-KBI yang wilayahnya jauh dari KBI dan telah memperoleh persetujuan dari Bank Indonesia, dengan jumlah bank peserta dan jumlah warkatnya sedikit.

b. Sistem Kliring Semi Otomasi

Pada tahun 1999 Bank Indonesia melakukan perbaikan dan penyempurnaan Sistem Semi Otomasi Kliring Lokal (SOKL) sebagai langkah persiapan menghadapi maslah komputer tahun 2000, tetapi belum ditetapkan dalam bentuk ketentuan. Ketentuan tentang penyelenggaraan kliring lokal secara semi otomasi ditetapkan kembali sebagai pengganti ketentuan yang disusun pada Maret 1993.

Sistem SOKL dilaksanakan pada semua Kantor Bank Indonesia yang belum melaksanakan sistem kliring otomasi atau elektronik, pada penyelenggara bukan Bank Indonesia, dan pada kliring pengembalian di Kantor Bank Indonesia yang sudah melaksanakan sistem kliring otomasi dan elektronik.

c. Sistem Kliring Otomasi

Sejak berlakunya Peraturan Bank Indonesia tahun 1999 tentang penyelenggaraan kliring lokal, Bank Indonesia merangkum semua ketentuan 
lama tentang kliring lokal secara otomasi untuk disesuaikan dengan Peraturan Bank Indonesia tersebut serta menerbitkannya dalam bentuk surat edaran.

Sistem kliring otomasi hanya diselenggarakan oleh Bank Indonesia. Semua bank termasuk bank konvensional yang memiliki unit usaha syariah dan berkantor di suatu wilayah kliring yang menerapkan sistem kliring otomasi, dapat menjadi peserta langsung atau peserta tidak langsung dengan memenuhi persyaratan yang ditetapkan oleh Bank Indonesia. Clear band atau magnetic ink character recognition (MICR) code line setiap warkat harus diisi dengan menggunakan mesin dengan tinta khusus (mesin encoder) untuk menulis sandi-sandi.

Dalam sistem ini tidak ada pertemuan kliring sehingga wakil peserta tidak diperlukan, namun diperlukan petugas yang mengantarkan warkat dan dokumen kliring. Petugas tersebut diwakili oleh pegawai peserta atau petugas dari perusahaan jasa kurir. Perusahaan jasa kurir mewakili peserta dalam kliring hanya untuk penyerahan dan penerimaan warkat, penerimaan laporan hasil proses kliring dan penerimaan pengumuman yang bersifat tidak rahasia yang disampaikan oleh penyelenggara.

d. Sistem Kliring Elektronik

Kliring yang dilakukan oleh Kantor Bank Indonesia dengan jumlah bank peserta dan jumlah warkat yang sangat banyak dilakukan dengan sistem kliring elektronik. Pada sistem kliring ini proses perhitungan, rekapitulasi, dan pembuatan laporan kliring (Bilyet Saldo Kliring) dilakukan secara elektronik melalui terminal elektronik di bank peserta kliring, sehingga tidak perlu datang ketempat kliring untuk menyampaikan warkat kliring.

Untuk pertukaran warkat dan rekonsiliasi dilakukan secara otomasi melalui komputer pusat kliring elektronik. Dengan sistem ini, proses kliring dapat diselesaikan dengan lebih cepat, akurat dan aman, serta mengurangi resiko tidak terprosesnya warkat kliring. Dalam pemrosesan data secara elektronik, mesin akan membaca Magnetic Ink Character Renognition (MICR) pada tiap lembar cek nasabah.

e. Sistem Kliring Nasional Bank Indonesia (SKNBI)

Sistem Kliring Nasional Bank Indonesia yang selanjutnya disebut SKNBI adalah sistem transfer dana elektronik yang meliputi kliring debet dan kliring kredit, yang penyelesaian setiap transaksinya dilakukan secara nasional.

Sejak dioperasikan oleh Bank Inonesia pada tahun 2005, SKNBI berperan penting dalam pemrosesan aktivitas transaksi pembayaran, khususnya untuk memproses transaksi pembayaran yang termasuk Retail Value Payment System (RVPS) atau transaksi bernilai kecil (retail) yaitu transaksi dibawah Rp.100 juta.

\section{Peserta Kliring}

a. Peserta Langsung Aktif (PLA)

Merupakan bank-bank yang sudah tercatat sebagai peserta kliring dan dapat memperhitungkan warkat atau notanya secara langsung dengan Bank Indonesia selaku lembaga kliring. Peserta ini memiliki wewenang untuk mengirimkan Data Keuangan Elektronik (DKE) ke Sistem Pusat Komputer 
Kliring Elektronik (SPKE) dan menyampaikan bundel warkat kepada penyelenggara. Peserta Langsung Aktif ini juga menerima hasil perhitungan kliring dan warkatnya dari penyelenggara dengan menggunakan identitas peserta yang bersangkutan.

b. Peserta Langsung Pasif (PLP)

Peserta ini mempunyai wewenang mengirimkan Data Keuangan Elektronik (DKE) ke Sistem Pusat Komputer Kliring Elektronik (SPKE) dan menyampaikan bundel warkat kepada penyelenggara melalui dan menggunakan identitas Peserta Langsung Aktif (PLA). Peserta ini tidak dapat menerima hasil perhitungan kliring dan warkat dari penyelenggara menggunakan identitasnya.

c. Peserta Tidak Langsung (PTL)

Peserta ini mempunyai wewenang mengirimkan DKE ke SPKE dan menyampaikan bundel warkat kepada penyelenggara melalui dan menggunakan identitas PLA. Peserta ini menerima hasil perhitungan kliring dan warkat dari penyelenggara dengan menggunakan identitas Peserta Langsung Aktif (PLA) atau Peserta Langsung Pasif (PLP).

\section{Warkat Kliring}

Menurut Khasmir, dalam bukunya Bank dan Lembaga Keuangan Lainnya, macam-macam warkat yang dapat dikliringkan adalah sebagai berikut:

a. Cek (Cheque)

Cek merupakan surat perintah tanpa syarat dari nasabah kepada bank yang memelihara rekening giro nasabah tersebut, untuk membayar sejumlah uang kepada pihak yang disebutkan didalamnya atau kepada pemegang cek tersebut.

b. Bilyet Giro (BG)

Merupakan surat perintah dari nasabah kepada bank yang memelihara rekening giro tersebut, untuk memindahbukukan sejumlah uang dari rekening yang bersangkutan kepada pihak penerima yang disebutkan namanya atau nomor rekening pada bank yang sama atau bank yang lainnya melalui kliring.

c. Wesel Bank Untuk Transfer

Merupakan wesel yang diterbitkan oleh bank khusus untuk sarana transfer.

d. Surat Bukti Penerimaan Transfer dari Luar Kota

Merupakan surat bukti penerimaan transfer dari luar kota yang dapat ditagih kepada bank penerima dana transfer melalui kliring lokal.

e. Lalu Lintas Giral (LLG) / Nota Kredit

Merupakan warkat yang digunakan untuk menyampaikan dana pada bank lain untuk untung bank atau nasabah yang menyampaikan warkat tersebut.

f. Nota Debet

Merupakan warkat yang digunakan untuk menagih dana pada bank lain untuk untung bank atau nasabah yang menyampaikan warkat tersebut. 


\section{Transaksi Kliring}

Dalam setiap melaksanakan kegiatan kliring terdapat berbagai macam tahap transaksi kliring. Muhammad dan Dwi Suwiknyo, dalam bukunya Akuntansi Perbankan Syariah, mengemukakan bahwa macam transaksi kliring yang dimaksud adalah:

a. Pelimpahan dana dari nasabah atau bank satu ke nasabah bank lainnya; dan

b. Penagihan oleh bank satu terhadap bank lainnya.

Tolakan Kliring

Warkat-warkat yang dikliringkan tidak semuanya tertagih, bahkan setiap transaksi kliring terdapat beberapa warkat yang ditolak pembayarannya. Ada beberapa alasan penolakan kliring pada saat penerimaan warkat-warkat kliring dalam kliring masuk. Alasan-alasan tersebut meliputi:

a. Asal cek atau Bilyet Giro (BG) salah;

b. Tanggal cek atau Bilyet Giro (BG) belum jatuh tempo;

c. Materai tidak ada atau tidak cukup sesuai dengan peraturan yang berlaku;

d. Jumlah yang tertulis di angka dan huruf berbeda;

e. Tanda tangan dan atau cap perusahaan tidak sama dengan specimen (contoh tanda tangan), atau tidak lengkap;

f. Coretan atau perubahan tidak ditandatangani;

g. Cek atau Bilyet Giro (BG) sudah kadaluwarsa;

h. Resi belum kembali;

i. Endorsment cek tidak benar;

j. Rekening sudah ditutup;

k. Dibatalkan penarik;

1. Rekening diblokir oleh pihak berwajib; dan

m. Kondisi cek atau Bilyet Giro (BG) tidak sempurna.

\section{METODE PENELITIAN}

Untuk metode penelitian, pengumpulan data dilakukan dengan dua cara yaitu:

a. Riset Perpustakaan (Library Research)

Yaitu pengumpulan data dengan cara mempelajari teori-teori dari literatur dan buku-buku yang ada kaitannya dengan objek penelitian.

b. Riset Lapangan (Field Research)

Yaitu melakukan penelitian langsung untuk mendapatkan data primer dan data sekunder.

Dalam menganalisa data, penulis menggunakan metode analisa data kualitatif sebagai metode penelitian yang menjelaskan secara deskriptif mengenai mekanisme pelaksanaan kliring pada Kantor Perwakilan Bank Indonesia Provinsi Sumatera Barat. Metode analisa ditinjau dari dua segi yang berbeda yaitu antara teori dan praktek sehingga dapat diketahui sejauh mana pelaksanaannya, apakah perbedaan yang timbul menyangkut prinsip dasar konsep itu sendiri. Dengan menganalisa perbandingan, pertanyaan itu akan terjawab selanjutnya dan hasil analisa itu dipergunakan sebagai dasar pengambilan kesimpulan dan saran. 


\section{HASIL DAN PEMBAHASAN Mekanisme Kliring}

Sebagai salah satu upaya untuk mewujudkan sistem pembayaran yang efisien, cepat, aman dan handal maka Bank Indonesia menerapkan Sistem Kliring Nasional Bank Indonesia (SKNBI) yang dapat mengakomodir transfer kredit antar bank ke seluruh wilayah Indonesia tanpa kewajiban melakukan pertukaran fisik warkat, serta dalam kaitannya untuk mengurangi risiko Bank Indonesia sebagai penyelenggara kliring diterapkan mekanisme Failure to Settle (FtS).

Sistem Kliring Nasional Bank Indonesia (SKNBI) sendiri adalah sistem kliring Bank Indonesia yang meliputi kliring debet dan kliring kredit yang penyelesaian akhirnya dilakukan secara nasional. Sejak dioperasikan oleh Bank Inonesia pada tahun 2005, Sistem Kliring Nasional Bank Indonesia (SKNBI) berperan penting dalam proses aktivitas transaksi pembayaran.

SKNBI diselenggarakan oleh:

a. Penyelenggara Kliring Nasional (PKN), yaitu unit kerja di Kantor Pusat Bank Indonesia yang bertugas mengelola dan menyelenggarakan SKNBI secara nasional; dan

b. Penyelenggara Kliring Lokal (PKL), yaitu unit kerja di Bank Indonesia dan bank memperoleh persetujuan Bank Indonesia untuk mengelola dan menyelenggarakan SKNBI di suatu wilayah kliring tertentu.

Penyelenggaraan SKNBI terdiri dari 2 (dua) sub sistem, yaitu:

a. Kliring Debet

1) Meliputi kegiatan kliring penyerahan dan kliring pengembalian untuk tansfer debet antar bank yang disertai dengan penyampaian warkat debet (cek, bilyet giro, nota debet, dan lain-lain);

2) Penyelenggaraan kliring debet dilakukan secara lokal disetiap wilayah kliring oleh PKL;

3) PKL akan melakukan perhitungan kliring debet berdasarkan DKE debet yang dikirim oleh peserta; dan

4) Hasil perhitungan kliring debet secara lokal tersebut selanjutnya dikirim ke Sistem Sentral Kliring (SSK) untuk diperhitungkan secara nasional oleh PKN.

b. Kliring Kredit

1) Digunakan untuk transfer kredit antar bank tanpa disertai penyampaian fisik warkat (paperless);

2) Penyelenggaraan kliring kredit dilakukan secara nasional oleh PKN; dan

3) Perhitungan kliring kredit dilakukan oleh PKN atas dasar DKE kredit yang dikirim peserta.

Kliring kredit dalam prosedur SKNBI diselenggarakan secara nasional oleh kantor pusat Bank Indonesia. Hal ini dimaksudkan agar pelaksanaan proses kliring dapat bersifat lebih efektif dan efisien, dengan tidak menyertakan fisik warkat (paperless) dan hanya menyerahkan Data Keuangan Elektronik (DKE) untuk diproses lebih lanjut.

Selain itu, pelaksanaan kliring kredit hanya dapat diselenggarakan jika bank peserta telah menyediakan dana awal (prefund) sebelum mengikuti 
kliring SKNBI. Tanpa adanya penyediaan dana yang berguna sebagai jaminan dalam kliring maka suatu bank tidak dapat mengikuti klliring.

Dengan diterapkannya mekanisme Failure to Settle (FtS), maka sebelum mengikuti kliring debet dan kliring kredit, bank wajib menyediakan pandanaan awal (prefund) untuk mengantisipasi pemenuhan potensi kewajiban dari seluruh kantor bank yang menjadi peserta pada penyelenggaraan kliring debet dan kliring kredit.

SKNBI terdiri dari 3 (tiga) komponen utama, yaitu sebagai berikut:

a. Sistem Sentral Kliring (SSK), merupakan komponen perangkat keras dan perangkat lunak yang digunakan oleh PKN;

b. Komputer Penyelenggara Kliring (KPK), merupakan komponen perangkat keras dan perangkat lunak yang digunakan oleh PKL; dan

c. Terminal Peserta Kliring (TPK), merupakan komponen perangkat keras dan perangkat lunak yang digunakan oleh peserta.

Sebagai salah satu Penyelenggara Kliring Lokal (PKL), Kantor Bank Indonesia Provinsi Sumatera Barat juga melaksanakan Sistem Kliring Nasional Bank Indonesia (SKNBI). Sama halnya dengan Pelaksana Kliring Lokal (PKL) lainnya, prosedur kliring yang dilaksanakan oleh Bank Indonesia Sumatera Barat adalah kliring debet.

Secara umum, mekanisme kliring debet adalah sebagai berikut:

1. Sebelum kegiatan kliring debet dimulai, bank wajib menyediakan pendanaan awal (prefund).

Batas minimum prefund adalah tagihan debet harian terbesar selama 12 (dua belas) bulan terakhir dengan mengeluarkan data outlier. Sedangkan jenis prefund kliring debet adalah dana tunai (cash prefund) dan atau agunan (collateral prefund). Jenis agunan dapat berupa Sertifikat Bank Indonesia (SBI), Sertifikat Wadiah Bank Indonesia (SWBI), Surat Utang Negara (SUN) dan atau surat berharga atau tagihan lain yang ditetapkan oleh Bank Indonesia.

2. Peserta membuat Data Keuangan Elektronik (DKE) debet berdasarkan warkat debet yang akan dikliringkan.

3.

Mengirimkan DKE debet dan warkat debet ke Pelaksana Kliring Lokal (PKL). Pengiriman DKE debet dapat dilakukan secara online maupun offline tergantung dengan jenis Terminal Peserta Kliring (TPK) yang digunakan oleh peserta.

4. Selanjutnya PKL akan melakukan penggabungan dan perekaman atas DKE debet yang telah lolos validasi. Sementara untuk warkat debet akan dipilah berdasarkan bank tertuju:

a. Secara otomasi dengan menggunakan mesin reader sorter berteknologi image, bagi PKL yang telah menerapkan sistem pilah warkat otomasi; atau

b. Secara manual oleh masing-masing peserta di lokasi PKL, bagi PKL yang belum menenerapkan sistem pilah warkat otomasi.

5. Atas dasar DKE debet yang diterima, PKL akan melakukan perhitungan kliring debet.

6. Penyelenggara Kliring Lokal (PKL) mengirimkan hasil perhitungan debet lokal ke Sistem Sentral Kliring (SSK). 
7. Mencetak laporan hasil kliring debet untuk selanjutnya didistribusikan kepada seluruh peserta bersamaan dengan warkat debet.

8. Setelah hasil perhitungan kliring debet lokal dari seluruh penyelenggara kliring diterima oleh SSK, selanjutnya akan dilakukan perhitungan kliring debet secara nasional.

9. Selanjutnya Sistem Sentral Kliring (SSK) melakukan simulasi Failure to Settle (FtS).

10. Apabila hassil perhitungan kliring debet nasional:

a. Bank "menang kliring (posisi kredit)", seluruh cash prenfund yang telah disediakan dikredit kembali ke rekening giro bank bersamaan dengan pengkreditan hasil kliring yang bersangkut.

b. Bank "kalah kliring (posisi debet)", sistem secara otomatis akan melakukan penyelesaian atas kewajiban bank tersebut dengan urutan sebagai berikut:

1) Pertama-tama sistem akan menggunakan cash prefund yang telah disediakan bank;

2) Apabila kewajiban bank masih lebih besar dari cash prefund, maka kekurangannya akan dipenuhi dari dana yang tersedia pada rekening giro bank;

3) Jika kewajiban bank masih lebih besar dari cash prefund dan saldo pada rekening giro, maka atas kekurangan saldo rekening giro bank tersebut, sistem akan menggunakan Fasilitas Likuiditas Intrahari Kliring (FLIKliring) atau Fasilitas Likuid itas Intrahari Syariah Kliring (FLISKliring) berdasarkan collateral prefund yang disediakan oleh bank;

4) Apabila kekurangan saldo rekening giro bank masih belum dapat dapat ditutup dengan FLI-Kliring/ FLIS-Kliring, maka kekurangan tersebut ditutup dengan surat berharga bank yang ada pada rekening FLI-RTGS/ FLIS-RTGS;

5) Pelunasan FLI-Kliring/ FLIS-Kliring dan FLI-RTGS/ FLIS-RTGS harus dilakukan sebelum tutup sistem BI-RTGS; dan

6) Apabila sampai dengan akhir hari FLI-Kliring/ FLIS-Kliring belum dapat dilunasi maka akan menjadi Fasilitas Pendanaan Jangka Panjang (FPJP) atau Fasilitas Pendanaan Jangka Panjang Syariah (FPJPS).

11. Setelah proses kliring debet selesai, peserta dapat memperoleh DKE Inward dengan cara men-download dari Sistem Sentral Kliring (SSK) atau dari Komputer Penyelenggara Kliring (KPK) melalui media rekam data elektronis (disket, flashdisk, atau CD).

\section{Peran Bank Indonesia Dalam Kliring}

Bank Indonesia mempunyai satu tujuan tunggal yakni mencapai dan menjaga kestabilan nilai rupiah. Dari segi pelaksanaan tugas dan wewenang, Bank Indonesia menerapkan prinsip akuntabilitas dan transparansi melalui penyampaian informasi kepada masyarakat luas secara terbuka melalui media massa setiap awal tahun mengenai evaluasi pelaksanaan kebijakan moneter dan penetapan sasaran-sasaran moneter pada tahun yang akan datang.

Sesuai Undang-Undang Nomor 3 tahun 2004 tentang perubahan atas Undang-Undang Nomor 23 tahun 1999 tentang Bank Indonesia, salah satu 
tugas Bank Indonesia adalah mengatur dan menjaga kelancaran sistem pembayaran. Di bidang sistem pembayaran, Bank Indonesia merupakan satusatunya lembaga keuangan yang mempunyai wewenang untuk mengeluarkan dan mengedarkan uang rupiah, serta mencabut, menarik, dan memusnahkan uang dari peredaran.

Di sisi lain dalam rangka mengatur dan menjaga sistem pembayaran, Bank Indonesia juga berwenang melaksanakan, memberi persetujuan dan perizinan atas penyelenggaraan jasa sistem pembayaran, seperti sistem transfer dana baik yang bersifat real time maupun kliring, ataupun sistem pembayaran lainnya.

Adapun peran Bank Indonesia yang berkaitan dengan sistem kliring adalah:

a. Penyelenggara Kliring

Lembaga kliring dibentuk oleh Bank Indonesia sejak tanggal 7 Maret 1967. Tempat kedudukan lembaga kliring adalah di Jakarta dan di kota-kota lain yang memungkinkan/ memerlukan adanya suatu perhitungan kliring antara bank-bank setempat. Kliring diselenggarakan oleh Bank Indonesia antara bank-bank di suatu wilayah kliring yang disebut kliring lokal.

Disamping itu mengingat Bank Indonesia sebagai bank pembina dan pengawas pada bank-bank umum dan bank-bank pembangunan, dalam ketentuan Undang-Undang Nomor 23 tahun 1999 Pasal 15 ayat (1) Bank Indonesia membina perbankan dengan jalan memperluas, memperlancar dan mengatur lalu lintas pembayaran giral dan menyelenggarakan kliring antar bank. Agar memperlancar pelaksanaan, kliring diawasi langsung oleh Bank Indonesia selaku penyelenggara.

Tujuan dilaksanakan kliring oleh Bank Indonesia antara lain:

1) Memajukan dan memperlancar lalu lintas pembayaran giral;

2) Perhitungan penyelesaian hutang-piutang dapat dilaksanakan lebih mudah, aman dan efisien; dan

3) Menjadi salah satu pelayanan bank kepada nasabahnya.

b. Mengatur Sistem Kliring Antar Bank

Sistem kliring antar bank meliputi sistem kliring domestik dan sistem lintas negara. Pengaturan kedua sistem ini mencakup antara lain:

1) Penetapan persyaraatan bagi Bank Indonesia atau bank dalam keanggotaan pada sistem kliring yang bersifat regional ataupun internasional.

2) Mengatur mengenai kesepakatan antar Bank Indonesia atau lembaga lain sebagai penyelenggara sistem pembayaran dengan baik serta lembaga penyelenggaraan sistem pembayaran negara lain yang berkaitan dengan pelaksanaan kliring dan penyelesaian akhir transaksi pembayaran antar bank.

c. Mengatur Pokok-Pokok Ketentuan Kliring

Pokok-pokok ketentuan dalam kliring yang diatur oleh Bank Indonesia adalah:

1) Jenis penyelenggaraan kliring yang dapat dilaksanakan pihak lain yang sudah mendapatkan persetujuan oleh Bank Indonesia; 
2) Persyaratan dan bentuk hukum pihak lain yang dapat menyelenggarakan kliring; dan

3) Tata cara pemberian persyaratan persetujuan pihak lain yang akan menyelenggarakan kliring

d. Mengatur Pembagian Wilayah Kliring

Penyelenggaraan kliring dibagi atas suatu wilayah-wilayah kliring, karena sampai dengan saat ini tidak dimungkinkan untuk penyelenggaran kliring terpusat pada suatu tempat yang disebabkan oleh banyaknya bank yang ikut dalam kliring. Oleh karena itu Bank Indonesia membagi suatu wilayah kliring atas pertimbangan sebagai berikut:

1) Geografis

Bank-bank peserta dalam suatu wilayah kliring harus memungkinkan untuk mengirimkan wakilnya mengikuti kliring yang dillaksanakan setiap hari kecualli hari libur, baik kliring return maupun kliring penyerahan.

2) Ekonomis

Bank-bank yang secara ekonomis mempunyai keterkaitan dalam transaksi-tarnsaksi perbankan cenderung untuk dimasukan dalam satu wilayah kliring tertentu.

\section{KESIMPULAN}

Kliring sebagai salah satu jasa pembayaran dan penagihan bagi nasabah pada Kantor Perwakilan Bank Indonesia Provinsi Sumatera Barat, dalam pelaksanaannya melakukan proses kegiatan kliring debet.

Berdasarkan penjelasan tentang mekanisme pelaksanaan kliring yang telah ada dan ditetapkan oleh Kantor Perwakilan Bank Indonesia Provinsi Sumatera Barat, dapat disimpulkan bahwa mekanisme pelaksanaan kliring yang dilaksanakan telah sesuai dengan sistem dan mekanisme Sistem Kliring Nasional Bank Indonesia (SKNBI) serta telah direalisasikan dengan baik, sehingga tingkat terjadinya kekeliruan maupun kesalahan dapat diminimalisir.

Namun adakalanya pelaksanaan kliring mengalami kendala yang menghambat proses kegiatan kliring. Kendala yang dimaksud adalah terjadinya gangguan koneksi dengan penyelenggara kliring nasional (Kantor BI Pusat) dalam melaksanakan kliring secara online karena terlalu banyaknya peserta kliring yang melaksanakan kliring secara online. Hal ini berdampak pada kegiatan kliring yang menyebabkan keterlambatan baik dalam memperoleh data maupun dalam mengirim data kliring.

\section{DAFTAR PUSTAKA}

Anwari, Achmad, (1985), Peranan Kliring dalam Dunia Perbankan, Penerbit Ghalia Indonesia, Jakarta.

Djiwandono, J. Soedradjad, dkk, (2010), Sejarah Bank Indonesia Periode VI, Penerbit Bank Indonesia, Jakarta.

Fernos, J, Dona, E (2018). Analisis Loan To Deposit Ratio, Capital Adequacy Ratio Dan Return On Assets PT. Bank Pembangunan Daerah Sumatera Barat. Jurnal Pundi 2 (2). 
Ghazali, Djoni. S dan Rachmadi Usman, (2010), Hukum Perbankan, Penerbit Sinar Grafika, Jakarta.

Hermansyah, (2008), Edisi Revisi Hukum Perbankan Nasional Indonesia, Penerbit Kencana Prenada Media Grup, Jakarta.

Kasmir, (2005), Bank dan Lembaga Keuangan Lainnya, Penerbit PT. Raja Grafindo Persada, Jakarta.

--------. (2008), Dasar-Dasar Perbankan, Penerbit PT. Raja Grafindo Persada, Jakarta.

---------. (2014), “Dasar-Dasar Perbankan” Edisi Revisi 2014, Penerbit PT. Raja Grafindo Persada, Jakarta.

Muhammad dan Dwi Suwiknyo, (2009), Akuntansi Perbankan Syariah, Penerbit Trust Media, Yogyakarta.

Rahmayeli, D. S., \& Marlius, D. (2017). Analisis Kinerja Keuangan Pada PT.

Bank Perkreditan Rakyat (BPR) Batang Kapas Pesisir Selatan. https://doi.org/10.31227/osf.io/sz5db

Shanjaya, A. R., \& Marlius, D. (2017). Peranan Laporan Keuangan Dalam Kebijaksanaan Pemberian Kredit Kepada Calon Nasabah Pada PT. BPR Batang Kapas. https://doi.org/10.31227/osf.io/uxmg6

Susilowati, Desi, (2010), Prosedur Pelaksanaan Kliring dalam Lalu Lintas Pembayaran Giral Antar Bank, Tugas Akhir Desi Susilowati, Universitas Sebelas Maret Surakarta.

Suyatno, Thomas, dkk, (2003), Kelembagaan Perbankan, Penerbit PT. Gramedia Pustaka Utama, Jakarta.

Triandaru, Sigit dan Totok Budisantoso, (2007), Bank dan Lembaga Keuangan Lain Edisi 2, Penerbit Salemba Empat, Jakarta.

http://www.bi.go.id 